\title{
Com vista para o mar: sobre a produção da imagem da Fortaleza vendável (Ceará, Brasil)
}

\section{With a sea view: the image production of a marketable city - Fortaleza (Ceará, Brazil)}

\author{
Monalisa Freitas Viana (VIANA, M. F.) ${ }^{*}$
}

\begin{abstract}
RESUMO - O trabalho toma como objeto de estudo a imagem da cidade de Fortaleza (Ceará, Brasil) forjada, principalmente, em âmbito governamental, e à qual se vinculam fortemente os elementos "sol e mar". Propõe-se aqui discutir sobre alguns dos diversos aspectos relacionados à produção dessa imagem: as estratégias de city-marketing estimuladas institucionalmente, as intervenções urbanísticas em consonância com esse discurso, bem como suas possíveis implicações socioambientais. Para tanto, fez-se necessário perceber a historicidade da ocupação e das formas de apropriação do ambiente litorâneo da cidade, sendo conveniente ressaltar os processos de "turistificação" e especulação imobiliária. A partir de uma pesquisa bibliográfica, o estudo aponta para a compreensão de tal imagem como parte de um processo gerador de impactos sobre a configuração e a paisagem da cidade.
\end{abstract}

Palavras-chave: Turismo; Zona litorânea; Fortaleza (Ceará, Brasil).

ABSTRACT - The paper presents as subject the image of Fortaleza (Ceará, Brasil) that is specially built on by governmental field and which is strongly linked to the elements: "sun" and "sea". The proposal is to discuss about some aspects related to this image production: the institutional strategy of city-marketing in different aspects, the urban interventions in line with this discourse and as well as its possible social-environmental implications. For that propose, it is necessary realizing the historic process of the coastal zone occupation in the city and the ways of this appropriation. For that, it is important to understand the "tourism process" and property speculation. Throughout a bibliographic research the study presents that image comprehension as part of a process which brings up impacts over the configuration of the city landscape.

Key words: Tourism; Coastal zone; Fortaleza (Ceará, Brasil).

\footnotetext{
* Licenciada em História pela Universidade Federal do Ceará (UFC). Tecnóloga em Gestão de Turismo pelo Centro Federal de Educação Tecnológica do Ceará (CEFET-CE). Especialização em Planejamento e Gestão Ambiental pela Universidade Estadual do Ceará (UECE). Bolsista de Extensão Tecnológica da Fundação Cearense de Apoio ao Desenvolvimento Científico e Tecnológico (FUNCAP), atuando no Sobrado Dr. José Lourenço, equipamento cultural vinculado à Secretaria da Cultura do Estado do Ceará SECULT. Endereço: Rua Major Facundo, 154 (Centro). CEP: 60.025-100 - Fortaleza - Ceará (Brasil). Telefone: (85) 8116.5770. E-mail: isafviana@gmail.com
} 


\section{INTRODUÇÃO}

A zona litorânea começa a se configurar enquanto espaço urbano de Fortaleza (Ceará, Brasil) com o movimento dos segmentos privilegiados demandando por mais uma área de lazer, levando para próximo das areias as suas segundas residências, de onde se podia ter "sob as vistas" o oceano Atlântico. Tal movimento a caminho do mar é intensificado com o passar do tempo e se dá de maneira conflituosa, ao passo da disputa entre os diferentes sujeitos pela produção daquele espaço.

Atualmente, a paisagem litorânea, com seus vários elementos componentes, tem figurado como principal identificador da cidade. Tal identificação resulta do processo construtivo da imagem de uma Fortaleza marítima que advém das transformações quanto às formas de apropriação da zona costeira.

Nesse sentido, a presente análise se sustenta sobre uma perspectiva dialética daquela imagem, a qual é compreendida tanto como resultante/indicativa de um dado modo de organização social e econômica, quanto como parte de um processo gerador de impactos sobre o ambiente, em seus diversos aspectos, exercendo influências sobre a própria configuração da cidade.

\section{A CAMINHO DO MAR}

Em função de seu porto, no século XIX, Fortaleza passa a participar de modo mais direto das atividades socioeconômicas do Ceará e, embora esse porto permitisse o escoamento da produção algodoeira para terras distantes, os olhos de Fortaleza ainda estavam voltados para o sertão (DANTAS, 2002). A vida social "decente" era resguardada no interior da cidade, entre prédios que davam as costas para o Atlântico. O mar era apenas o "instrumento" pelo qual a "civilidade" penetrava no cotidiano daqueles fortalezenses mais desejosos do requinte europeu: expressões em inglês apareciam nomeando lojas; empresários estrangeiros, estabelecidos na cidade, tornavam mais acessíveis, àqueles de melhor poder aquisitivo, toda sorte de produtos importados e tão cobiçados. O porto, nesse sentido, era o local de trocas e passou a ser também "lócus" promotor da aproximação da cultura e dos costumes europeus, em especial franceses. 
Dantas (2002, p. 34) afirma: “O papel da zona portuária, como janela voltada para a Europa, ao qual se acrescentava o de zona exportadora de produtos, provoca grande movimento de mercadoria e de pessoas na Praia de Formosa”. Porém, embora a movimentação à beira-mar tenha sido intensificada por essas atividades portuárias, os frequentadores resumiam-se a trabalhadores. Segmentos mais abastados permaneciam afastados da praia, por lá passando somente em condição de viajantes, para desembarque e embarque a destinos diversos.

Por outro lado, essa porção comerciante da praia, sob a condição de "janela para a Europa", possibilita à cidade exportadora mudanças em suas feições. Sobrados tornam-se mais frequentes; as fachadas das casas passam a adotar estilos importados, em especial da França como o Neoclássico, e o próprio traçado das ruas sofre alterações. Para tanto, Silva Paulet propõe, no início do século XIX, o Plano em Xadrez, o qual, para o arquiteto Liberal de Castro: “[...] está intimamente ligado a objetivos colonizadores ou de expansão urbana" (CASTRO, 1977, p. 30).

Aquele período é de suma importância. Inauguram-se os serviços de bonde de burro, iluminação pública, calçamento nas ruas centrais, telefones, telégrafo, cabo submarino; fundam-se as primeiras associações culturais e sociais, tentam-se os primeiros projetos de se dotar Fortaleza de um porto organizado. As atividades culturais entram em efervescência, propiciando o aparecimento de nomes que brilharão intensamente no cenário nacional (CASTRO, 1977, p. 34).

Aprovado em 1824, Fortaleza seguiria o plano quadrangular, expressão do crescimento econômico baseado na relação sertão-mar: as ruas principais seguiam rumo ao interior, em caminho norte-sul, cortadas pelas travessas de sentido leste-oeste (DANTAS, 2002). Percebe-se que a cidade se estendia ao sul, ao passo que o litoral devia sua razão funcional, sob a ótica econômica, ao sertão: a praia servia ao interior. Era vital, dessa maneira, tanto para a própria Fortaleza, quanto para as novas atividades litorâneas, manter essa ligação com o sertão.

Com esse objetivo, foi desenvolvido o sistema ferroviário, aumentando o contato da cidade do Pajeú com as regiões produtoras de algodão. Assim, Fortaleza, definitivamente, passa a fazer parte do quadro socioeconômico cearense. Através da linha-férrea (Fortaleza-Baturité - 1873), produtos do interior chegam aos consumidores da capital (GIRÃO, 1959). Eram as locomotivas que traziam tais produtos das regiões 
serranas de Maranguape, Pacatuba e Baturité, consideradas, ainda segundo Girão (1959), "celeiros" que complementavam quantitativa e qualitativamente os precários abastecimentos vindos das regiões de tabuleiro: Aquiraz, Cascavel e Pacajus.

Tencionando ampliar o traçado de Paulet, em 1875, o arruador Adolfo Herbster vai incluir três bulevares ao plano de expansão da cidade, orientando seu crescimento rumo a áreas mais periféricas, atingindo a oeste a atual Avenida do Imperador, a leste e sul, as linhas referentes às atuais vias Dom Manuel e Duque de Caxias, respectivamente (CASTRO, 1977). Diante disso, o norte litorâneo continuou fora do plano urbanístico, já que as atividades portuárias, lá desempenhadas, não demandavam urbanização, apenas a instalação de alguns equipamentos como a alfândega e armazéns.

Outra cidade sobrevivia na zona de praia, espaço que permaneceu destinado àqueles que não podiam frequentar os clubes, cinemas, teatros; àqueles marginalizados pelo plano urbanístico, cuja pretensão era organizar e embelezar a cidade na qual uma grande parte da população não poderia ser encaixada (JUCÁ, 2003). Ainda segundo o mesmo autor, em períodos de seca, principalmente, expulsos do centro, vários retirantes se estabeleciam junto a antigas comunidades pesqueiras, numa ocupação desordenada, dando início à formação de comunidades como o Arraial Moura Brasil.

Dantas (2002) esclarece que quase não se identificavam práticas relacionadas ao lazer à beira-mar. Que os banhos de mar, por sua vez, não eram identificados à diversão, mas à cura. Ainda, que as águas salinas conferiam ao banho de mar uma característica terapêutica, o que mais tarde vai contribuir para a instalação de chácaras à beira-mar, privilegiadas por receber a salutar brisa. $\mathrm{O}$ autor ainda afirma que, em fins do século XIX, os banhos de mar terapêuticos tornam-se comuns: tomando como exemplo o que ocorria na Europa, aos acometidos por doenças respiratórias era recomendada a vivência em locais de clima salutar de baixa umidade e ventos constantes. No Ceará, entretanto, a praia não representava preferência nos tratamentos dos males pulmonares, concorrendo, dessa forma, com regiões serranas e sertanejas (DANTAS, 2002).

Em razão da salubridade, o Ceará torna-se nacionalmente conhecido, atraindo fluxo expressivo de doentes que buscam se curar não apenas nas áreas de praia. Tuberculosos se estabelecem em cidades como Quixadá, Quixeramobim e Icó. Doentes com beribéri fixam-se nas regiões montanhosas, principalmente em Baturité (DANTAS, 2002, p. 36). 
As práticas marítimas ainda eram, pois, intermitentes, não justificando ocupação urbana da área. O litoral era paisagem desvalorizada, local de jogar e de esconder o que não se queria ver ou ter na cidade. Como bem rememora Otacílio de Azevedo (1992, p. 129-130), a praia era o lugar do que era sujo:

[...] era costume de quase todas as residências encher de detritos fecais enormes barris de madeira e mandarem atirar o malcheiroso conteúdo nas proximidades da praia. Eram levados à cabeça por homens acostumados a esse anti-higiênico mister. De onde quer que partissem, os quimoeiros passavam obrigatoriamente pela frente da Santa Casa, descendo o calçamento que dava no velho Gasômetro, rumo à praia. Ali chegando, o fétido carregamento era atirado ao mar $[\ldots]$.

Por volta das décadas de 20 e 30 do século XX, verifica-se que a cidade se expande para os altos estratos da sociedade, os quais se distanciam cada vez mais do Centro, transferindo seus lugares para outras direções, seguindo as diretrizes de expansão periférica do plano de Herbster, de 1875 (CASTRO, 1977). Essa extensão da cidade é possível com a contribuição do desenvolvimento dos transportes. Concomitantemente, uma nova dinâmica a caminho do mar se dá a partir de transformações quanto à significação do sol, resultando da valorização social do sol e dos ambientes litorâneos.

Segundo Dantas (2002), a cidade fica assim dividida: a leste e a norte de Fortaleza, a elite concentra o veraneio e seus espaços de lazer. Ao sul e oeste, formamse especialmente os bairros Benfica e Jacarecanga, que se fazem bairros habitacionais. Portanto, é nesse período que a praia passa a ser enxergada como espaço de lazer, concorrendo com o Centro e, em especial, com a Praça do Ferreira. Assim, os pobres que, obrigatoriamente, ocupavam a praia devido à política higienista e de controle e ordenamento social, a qual os expulsava do Centro, tem agora, na década de 30, que deixar também parte do litoral, diante da chegada de um segmento abastado (DANTAS, 2002).

Essa porção abastada é a empreendedora da urbanização da praia, no sentido de dotar o lugar de estrutura e equipamentos outros, inicialmente por meio do aparecimento das chácaras e segundas residências que serviam para o veraneio: "a linha do bonde, na rua dos Tabajaras, a consolida [Praia de Iracema] como espaço de lazer onde se concentram as primeiras residências secundárias" (DANTAS, 2002, p. 52). A 
nova mentalidade da camada alta, com relação ao litoral, é materializada através das construções, em 1926, da Vila Morena, por José de Magalhães Porto e, em 1929, da sede do Náutico Atlético Cearense (JUCÁ, 2003).

Com a "descoberta" da praia pela elite, determinados grupos (prostitutas, por exemplo) começam a ser impedidos de circular pela região da costa compreendida entre a Ponte Metálica e o Mucuripe, área resguardada às "pessoas de bem" (JUCÁ, 2003). Através de decreto expedido, já em 1924, pelo Serviço de Inspeção da Policia Marinha, as "indecentes" frequentariam um espaço restrito da orla. Como apontado por Jucá (2003, p. 141):

\begin{abstract}
A caça à falta de pudor e à libertinagem passava à deriva dos problemas sociais que mereciam ser encarados com pragmatismo. Por trás da indecência, pelo menos em considerável percentual, encontrava-se a miséria dos que se envolviam com a prostituição como saída de sobrevivência, forçada pelas circunstâncias.
\end{abstract}

Percebe-se daí, que o espaço litorâneo passou a ser um espaço de disputas entre antigas territorialidades (retirantes, comunidades pesqueiras) e as novas atividades promovidas pela elite (veraneio, banhos de mar), principalmente após o período da Segunda Grande Guerra (DANTAS, 2002). Vale salientar, ainda segundo o autor, que a área praiana que a elite agora reivindicava para si concentrava-se a leste, compreendendo as praias de Iracema e, a partir de 40, do Meireles. O autor ainda afirma que o oeste litorâneo, por outro lado, consolidava-se como região de pobreza.

Nos anos 40, o balneário foi prejudicado devido ao avanço das marés, resultante das obras do porto do Mucuripe, acarretando a destruição de muitas das casas, sobretudo na Praia de Iracema (JUCÁ, 2003). Tal obra também ocasionou o "emparedamento" dessa mesma praia com a construção de diques de retenção. Isso faz com que o espaço litorâneo para o uso abastado se alargue, alcançando a Praia do Meireles e a Praia do Mucuripe.

Em janeiro de 1950, a nova sede do Náutico Atlético Cearense é inaugurada na praia do Meireles (JUCÁ, 2003). O clube era símbolo de elegância, apresentando uma arquitetura requintada. Segundo o mesmo autor em 1954, inaugura-se o Iate Clube. Ambos faziam daquela área um lugar mais nobre, conferindo-lhe pompa.

O movimento de expansão empreendido pelos bem aquinhoados aponta para um planejamento urbano extremamente excludente e ditado, sempre, pelos donos do capital. 
Através da ocupação da costa marítima pela camada privilegiada, o rearranjo da cidade é ocasionado, e as camadas populares, antes escondidas na faixa de praia, no momento em questão, são de lá retiradas. A presença delas ofuscava, poluía o novo ambiente da elite. Essa visão se solidificava, de acordo com Jucá (2003), principalmente através da ação da prefeitura na década de 40, que previa o desmonte de diversos casebres situados entre as praias de Iracema e do Mucuripe. A população carente seria transferida, com isso, para a região além porto. "A preocupação com isolar a pobreza parecia o melhor remédio para salvaguardar a cidade" (JUCÁ, 2003, p. 53).

Na década de 50, a movimentação nas praias, em especial na praia do Iate Clube, era intensa, tornado-as alvo de sujeira, além de criar a necessidade da instalação de postos de salvamento, o que aconteceu na praia do Meireles (JUCÁ, 2003). Ainda segundo o autor por essa época, a praia de Iracema já não era mais a mesma, desde a implantação do porto do Mucuripe; enquanto a Praia de Formosa passava a concentrar prostíbulos e casebres.

Segundo Dantas (2002), a integração da praia ao perímetro urbano é concretizada pela abertura da Av. Beira-Mar no Meireles, em 1963, seguindo diretrizes do Plano Diretor de Fortaleza de 1962. Essa avenida tornar-se-ia posteriormente um dos principais cartões-postais da Fortaleza turística. Como expõe Coelho (2006, p. 21):

[...] sendo a urbanização uma transformação da sociedade, os impactos ambientais promovidos pelas aglomerações urbanas são, ao mesmo tempo, produto e processo de transformações dinâmicas e recíprocas da natureza e da sociedade estruturada em classes sociais.

Nesse sentido, vai tornando-se mais marcante o processo de segregação/ diferenciação entre os espaços da cidade, bem como a constituição dos diversos territórios.

\section{FORTALEZA TROPICALIENTE: UMA INICIATIVA GOVERNAMENTAL}

Com a ampla "turistificação" do espaço litorâneo, várias cidades nordestinas têm participado de uma ferrenha concorrência, disputando entre si a atenção lucrativa do visitante (BENEVIDES, 1998). Para tanto, as estratégias de marketing possibilitam maior visibilidade à cidade em disputa. Como uma vitrine, ela deve apresentar-se a mais 
convidativa, de forma que o cliente atraído entre e, motivado o bastante, deixe ali o máximo que puder de sua renda. Dessa maneira, ainda segundo o autor, a produção de imagens passa a receber capital importância para o desenvolvimento da atividade em questão, por exercer ela - a imagem - um forte poder de atração.

Considera-se que a relação sociedade-natureza está embasada sobre a forma como a própria "sociedade se organiza para o acesso e uso dos recursos naturais" (BERNARDES e FERREIRA, 2003, p. 19). Assim, a natureza adquire significações e valores outros. Seguindo o pensamento de Bernardes e Ferreira (2003), pois, os valores são produzidos a partir da relação social. A produção para troca implica em uma relação diferenciada com a natureza - diferenciada daquela que consiste no suprimento das necessidades básicas de existência. Fala-se aqui, portanto, em produção, tendo-se em vista que o espaço litorâneo da cidade vem sendo produzido para atender às novas necessidades: do mercado, seja por meio dos negócios imobiliários ou do turismo de massa.

Coriolano (1998) ressalta que o turismo litorâneo emerge quando há valorização social tanto do mar quanto do sol. Diante disso, muitos países tropicais começam a despertar outros sentimentos ligados a descanso e lazer, e deixam de ser constantemente relacionados a doenças e exotismo, principalmente após a Segunda Guerra Mundial.

Anteriormente, discutiu-se acerca do processo pelo qual Fortaleza se volta para o mar, mas é a partir dos anos 70 que políticas públicas tendem a voltar para o turismo a área litorânea da capital. É quando a urbanização se dá de maneira mais intensa. Aragão (2005) ressalta que foi o governo César Cals (1971-1974) que lançou as sementes para a formulação da atual imagem de "Fortaleza, Cidade da Luz". Já no plano urbanístico destaca-se, por exemplo, durante o governo de Adauto Bezerra (1975-1970), a instalação do Polo de Lazer (Praça 31 de Março) na Praia do Futuro; o prolongamento da Avenida Beira-Mar e o prolongamento também da Avenida Santos Dumont, em 1976, permitindo a conexão do Centro e da Aldeota à Praia do Futuro, a qual passou, a partir de então, por um processo de ocupação (CORIOLANO, 1998) ${ }^{1}$.

\footnotetext{
${ }^{1}$ A ocupação mais intensa da Praia do Futuro se deu nos anos 80, quando da criação de linhas de ônibus que circulassem de bairros da periferia até as praias de Iracema e do Meireles, como a linha Grande Circular. Isso facilitou a chegada de populares à área, até então, reservada ao lazer dos privilegiados. Estes, diante de tal fato, encontram na Praia do Futuro uma "fuga" (DANTAS, 2002).
} 
Conforme Dantas (2002), com o governo Virgílio Távora (1979-1982), a Avenida Beira-Mar se concretiza como espaço turístico, ao mesmo tempo em que sua paisagem é transformada, a partir da localização de arranha-céus, tanto residenciais quanto destinados ao ramo hoteleiro onde, até então, estavam situados pequenos restaurantes e residências de pescadores e de classe média. De acordo com Silva (2001), esse movimento havia se iniciado com a substituição do ar bucólico dos quintais e jardins do Meireles por edifícios, em princípio, com três pavimentos sobre pilotis. Os calçadões margeando a praia também vêm afirmar a zona costeira como lugar de encontros e lazer. Desse modo, o primeiro foi realizado na Avenida Beira-Mar, 1982, o qual se estendeu à Praia de Iracema na década de 1990, mesmo período em que o da Praia do Futuro é construído, cuja extensão vai desde o porto do Mucuripe à barra do rio Cocó (DANTAS, 2002).

Essa nova "era" da orla marítima fortalezense se consolida nos anos 90 com o "Governo das Mudanças"2. Esse governo assume características bem marcantes no que tange ao desenvolvimento da atividade turística. Adotando uma postura arrojada, fomentou o Programa de Ação para o Desenvolvimento do Turismo no Ceará (PRODETUR-CE), ${ }^{3}$ um marco da atividade no Estado, além de ressaltar a lucrativa identidade entre a cidade e a orla marítima através da publicidade, sob as suas mais diversas formas. O conjunto "sol e mar" passou a ser apresentado como importante agente motivador de viagens ao Ceará.

A respeito das motivações para viajar é importante mencionar que para algumas pessoas a decisão de fazer uma viagem parte da necessidade de busca pelo lugar dos sonhos, onde se possa realizar tudo aquilo que a vida diária e habitual reprime. Assim, a produção de imagens fixa suas bases, justamente, sobre as fantasias e os desejos preexistentes do viajante em potencial. O local receptor deve ser exibido, portanto, como o mais próximo de um lugar encantado e de 'gente feliz'. Nesse lugar não existem contradições nem conflitos (BENEVIDES, 1998).

\footnotetext{
${ }^{2}$ Período político iniciado com o primeiro mandato de Tasso Jereissati (1987-1990), continuado pelo governo Ciro Gomes (1991-1994) e por mais dois mandatos de Jereissati (1995-1998 / 1999-2002). Tal geração assume uma postura mais empresarial no que tange à política econômica e apresenta-se como possibilidade de modernização e oposição ao Regime Militar que chegava ao fim (GONDIM, 2001; ARAGÃO, 2005).

${ }^{3}$ Derivado do PRODETUR-NE, projeto que tem como objetivo o desenvolvimento da atividade turística no litoral nordestino, e que foi iniciado em $1992 \mathrm{com}$ a reunião de governantes de vários estados do Nordeste (BENEVIDES, 1998; DANTAS, 2002).
} 
Segundo o argumento de Benevides (1998, p. 92), o marketing turístico “[...] toma as parcelas radiosas e atraentes dessas cidades e as veicula, como se mostrassem o seu todo". Para ele, o lado positivo da cidade é, pois, realçado, tomando até mesmo formas e proporções distorcidas. Ainda segundo o autor, por vezes, a imagem se distancia tanto da realidade, que acaba por reforçar, no imaginário do turista, a quimera de uma cidade inexistente, feita apenas de papel e tinta. Uma miragem.

O espaço turístico é, pois, um espaço socialmente produzido, tendo-se em vista que a atratividade do local não se encerra apenas na própria existência física do espaço, mas é fruto de uma produção social, pois está fundamentada no imaginário da sociedade pós-industrial. A publicidade, através de pesquisas, aproxima-se desse imaginário com o objetivo de "oferecer" o ideal de lugar, e assim o produto turístico é criado, ao mesmo tempo em que “[...] estimula e alimenta o mito, fechando o negócio" (CORIOLANO, 2005, p. 115).

Nas fotografias publicitárias, então, busca-se identificar Fortaleza à "nova orla", onde os arranha-céus se elevam imponentes, conferindo à cidade uma atmosfera de “moderna metrópole". Conjuga-se aí, na mesma fotografia, a vista encantadora do mar e a ideia de cidade dotada de confortos e facilidades para atender até os gostos mais requintados. A imagem (iconografia), nesse contexto, não é apenas ilustrativa, mas apresenta, ela própria, um discurso.

Cabe aqui ressaltar que uma fotografia não é a realidade pura congelada; ao contrário, ela é uma construção carregada de subjetividade e contenedora de versões do real. Fruto de seleções e intencionalidades, ela é um recorte da realidade, o qual expõe uma porção do real, enquanto outras mais são silenciadas.

A descrição da cidade é assim composta nos informativos: pela fotografia, rica em símbolos e ícones complementados pelos textos escritos, os quais trazem, como denomina Meireles (1994), expressões-chave que remetem à ideia de cenário espetacular - "águas mornas, céu azul, brisa marinha, vento suave, gente acolhedora, mar de águas verdes, sol forte". Tal descrição é afirmada pela presença de alguns dados geográficos ${ }^{4}$, tais como: temperatura média anual da cidade $\left(27{ }^{\circ} \mathrm{C}\right)$, extensão da faixa

\footnotetext{
${ }^{4}$ Fonte: "Ceará. Ninguém tira da cabeça" (folder de divulgação), "Ceará. Ninguém tira da cabeça" (Guia Turístico de Fortaleza, 2006) e "Ceará. Quem conhece só fala bem" (Mapa turístico de Fortaleza, 2006), produções da Secretaria do Turismo do Governo do Estado do Ceará. "Fortaleza. Você vai amar essa cidade" (Guia de Fortaleza, 2006), produção da Secretaria de Turismo de Fortaleza.
} 
de praia em quilômetros (573 Km de litoral cearense) e até mesmo o tempo, em horas, durante o qual a cidade fica exposta ao sol (2800 horas/ano).

A veiculação de tais características revela a iniciativa dos poderes estadual e municipal (pois muitos desses informativos são produzidos pela Secretaria do Turismo do Estado do Ceará - SETUR e Secretaria de Turismo de Fortaleza - SETFOR) de apoiar a exploração econômica do espaço litorâneo, consolidando o turismo de "sol e mar". Para tanto, a concepção de sol vem sofrendo mutações, “[...] as pródigas energias solares e o clima passam agora a ser considerados insumos estratégicos" (BENEVIDES, 1998, p. 37). O sol, antes representante de seca e estiagem, é agora, em reunião com o mar, relacionado ao lazer. O conjunto "mar e sol" tornou-se um convite à viagem. Com isso, o Ceará, e mais especificamente Fortaleza, é vista sob uma nova ótica, e o chavão "Terra da Luz" adquire outra significação. Fortaleza, passou, nesse ínterim, “[...] de capital da seca e da miséria, para 'Miami do Nordeste' ou mesmo 'Caribe Brasileiro'” (GONDIM, 2001, p. 8).

Percebe-se que todo esse trabalho publicitário, porém, não tem bases suspensas no ar, mas é calcado na natureza essencialmente superficial do indivíduo enquanto turista, ou seja, a principal meta desse turista, ao realizar uma viagem, não é a análise da sociedade do local receptor, percebendo suas incoerências, mas é justamente o contrário: a fuga do real (CORIOLANO, 2005). Cabe, entretanto, àqueles estabelecidos na cidade, aos que nela residem e aos que nela empreendem seus negócios, inclusive os turísticos, a postura crítica.

Mesmo que o turismo já viesse sendo praticado desde a década de 70, e mesmo antes, foi com o "Governo das Mudanças" que, na vida econômica do estado, ele foi encarado de maneira mais sistemática e colocado no mesmo patamar que a indústria tradicional ocupava, propondo-se um planejamento mais amplo e de acordo com a complexidade da atividade, no que diz respeito à infraestrutura necessária, e aos incentivos fiscais a possíveis empreendedores do ramo.

Seguindo o argumento de Gondim (2001), tanto o governo estadual quanto o municipal viam o turismo como o mediador da construção da moderna capital, convergindo suas ações para a formação da imagem de Fortaleza como um "animado balneário", de forma a atrair não só turistas, mas investidores que, sob uma série de

\footnotetext{
${ }^{5}$ Termo utilizado em referência ao fato da província do Ceará ter declarado a abolição da escravatura em 1884, quatro anos antes da Lei Áurea (1888).
} 
incentivos, acabariam por enxergar em Fortaleza um local bastante promissor. O city marketing agiria em duas esferas: vendendo a cidade externamente, ao mesmo tempo em que garantiria maior visibilidade às realizações do governo e à sua própria figura, procurando exercer uma certa influência sobre a maneira de ver a cidade do "espectador" local.

O vínculo entre as estratégias de marketing turístico e político emerge, pois, apoiado no binômio "sol e mar". As campanhas englobam os mais variados veículos da comunicação nacional e internacional. Voltada para o mercado nacional, é veiculada em 1987, por exemplo, a campanha “Ceará, sinta na pele esta magia” (MEIRELES, 1994). Em 1990, com bases firmadas sobre as potencialidades decodificadas a partir dos trabalhos do Programa de Desenvolvimento do Turismo em Zona Prioritária do Litoral do Ceará (PRODETURIS) ${ }^{6}$ - clima, gastronomia, vida noturna, hospitalidade e compras - a campanha "Ceará, Terra do Sol", que trazia como reforço figuras de cearenses famosos como José Wilker, Renato Aragão, Luiza Tomé, Fagner e Milton Moraes, ganha prêmio de marketing (MEIRELES, 1994).

Apontando interesse internacional, em 1991, é veiculada na Argentina a campanha "El Caribe Brasileño" que, conforme dados apresentados por Meireles (1994, p. 27), teve um custo de U\$ 400 mil em junho de 1992 e rendeu, na alta estação de 1993, U\$ 21 milhões. De acordo com a autora, o sonho dos argentinos de ir ao Caribe fundamentava a campanha em questão, na qual se comparava as praias caribenhas às cearenses, ressaltando os preços bem mais acessíveis dessas últimas.

Sob a justificativa de estar investindo nas potencialidades locais, o governo cede recursos à produção de telenovelas, em parceria com a Rede Globo, a maior rede de televisão nacional (DANTAS, 2002; GONDIM, 2001). Com isso, em 1994, durante o governo de Ciro Gomes, "Tropicaliente" vai ao ar exibindo para todo o Brasil paisagens litorâneas: Porto das Dunas (Aquiraz), em cena como a aldeia de pescadores; Barra Nova (Beberibe); e Cumbuco (Icaraí), onde as casas de personagens ricas se localizavam. Além dos cenários naturais, o grande empreendimento privado, Beach Park, aparecia como o 'Gran Parque Gitano'; o Shopping Iguatemi, o Centro de Turismo e a rua comercial Monsenhor Tabosa também serviram de set de gravação.

\footnotetext{
${ }^{6}$ O Programa de Desenvolvimento do Turismo em Zona Prioritária do Litoral do Ceará, de 1989, forneceu bases conceituais e técnicas para o PRODETUR-CE (DANTAS, 2002).
} 
Conforme Meireles (1994) e Gondim (2001), essa produção ocorreu com o auxílio financeiro concedido pelo Estado, diante da condição de que só se apresentasse a porção "nobre" da cidade, aquela dotada de infraestrutura. De acordo com o anuário de 1994, o fluxo turístico aumentou ocasionado pela novela, e os hotéis tiveram média de 70\% de ocupação naquele ano (IPLANCE, 1995).

Em 1998, "Meu bem-querer" também foi gravada sob aquelas mesmas condições de produção e finalidades (DANTAS, 2002; GONDIM, 2001). Dantas (2002, p. 98) apresenta ainda um depoimento do diretor de novelas global, Marcos Paulo, que afirma: “[...] as cenas dessas novelas são gravadas conforme fórmula simples que procura, a partir da apresentação da paisagem litorânea a espectadores, desenvolver a indústria turística".

Ainda de acordo com Dantas (2002), a Lei Jerreissati (Lei Estadual de Investimentos Fiscais à Cultura), de 1995, destinou verbas a projetos cinematográficos que seguiram a mesma "linha publicitária" das novelas. Assim, em 1997, o filme "A ostra e o vento" é rodado em Jericoacoara e Fortaleza. Além dele, outros como " $O$ noviço rebelde" e "Bela Donna"7 apresentam a costa cearense que, através da tela do cinema, chega ao imaginário de milhares de espectadores.

Todas essas iniciativas confirmam a posição do litoral como vetor do desenvolvimento econômico por meio do turismo; e solidificando essa tendência, intervenções urbanísticas são implementadas em Fortaleza. São exemplos as obras de embelezamento da Avenida Beira-Mar (1988); a reforma da Ponte dos Ingleses (1992); a restauração das fachadas do casario que rodeia o Centro Dragão do Mar de Arte e Cultura; a própria construção desse Centro Cultural; a construção de calçadões nas praias de Iracema, do Futuro e Leste-Oeste; bem como o melhoramento das vias de acesso à Praia do Futuro (ARAGÃO, 2005; GONDIM, 2001). Todas, obras que capacitariam a região litorânea à circulação de turistas. Nessa conjuntura, compreendese a afirmação de Gondim (2001, p. 12) sobre a possibilidade de "[...] identificar um conjunto de símbolos que traduzem valores, sentimentos e aspirações relativos à vida urbana ainda que se reconheça que estes possam ser evocados por elementos materiais".

Tais administradores, que buscam tornar Fortaleza polo turístico, solicitam também a colaboração da população local no que diz respeito a receber bem o visitante.

\footnotetext{
${ }^{7}$ Gravados em Jericoacoara e Canoa Quebrada, respectivamente (DANTAS, 2002).
} 
Através de propagandas, busca-se "conscientizar" os moradores de que "turista bem tratado volta sempre" e reforçar, desse modo, a identidade do cearense (e consequentemente do fortalezense) como um povo hospitaleiro e alegre. E assim, o paraíso dos folders e outdoors se completa: mar, sol radiante e gente feliz. Convém, todavia, enxergar além do que está explícito na fotografia ou no vídeo, e perceber outra face da relação da cidade com o mar, uma relação que está latente nas imagens divulgadas.

A descrição de uma das cidades (Fedora) de Ítalo Calvino (1990) leva à reflexão, e uma questão emerge: quão próximos e/ou distantes estão imagem e cotidiano de uma mesma cidade, de uma mesma Fortaleza?

\footnotetext{
Dentro de cada esfera, vê-se uma cidade azul que é modelo para uma outra Fedora. São as formas que a cidade teria podido tomar se, por uma razão ou por outra, não tivesse se tornado o que é atualmente. Em todas as épocas, alguém, vendo Fedora tal como era, havia imaginado um modo de transformá-la na cidade ideal, mas, enquanto construía seu modelo em miniatura, Fedora já não era mais a mesma de antes e o que até ontem havia sido um possível futuro hoje não passava de um brinquedo numa esfera de vidro (CALVINO, 1990, p. 32).
}

Através desse apanhado geral das iniciativas governamentais no âmbito publicitário, torna-se perceptível que o Estado dispensou maciços investimentos e dedicou grande "esmero" à formulação e veiculação de imagens de uma Fortaleza ideal, com vista para o mar e bem ao alcance de "todos". E quanto ao real da cidade? Terá recebido o mesmo cuidado que as "miniaturas"?

\section{CONSIDERAÇÕES FINAIS: PAISAGEM CONSTRUÍDA}

Entende-se paisagem a partir da ideia de "visão de conjunto", no qual os objetos nela contidos estão relacionados. Nesse sentido, uma paisagem é redefinida/reestruturada ao passo das transformações nas relações entre seus componentes. É marcada, assim, pela dinâmica dos processos sociais (ARANTES, 1997).

Uma cidade, portanto, ultrapassa a funcionalidade de mera habitação, e assume uma dimensão "literal", tornando-se um enérgico agente de indagação do real e das 
suas próprias condições de produção: Quem a produz? Para quem? Que memórias, identidade e projetos constrói ou apaga? Nesse sentido, a História é um campo rico para esse processo de leitura, pois, citando Silva Filho (2003, p. 20), “[...] perceber na paisagem urbana vestígios de tempos plurais implica também indagar sobre sua própria época, o que a distingue das demais, quais seus desafios e encantos que guarda, que misérias e opressões são perpetuadas diariamente, sob as vistas de todos".

Conforme visto, por volta dos anos 80, a corrida pela melhor vista em Fortaleza tem início, e cada metro quadrado de frente para o mar passa a custar fortunas e a gerar muito mais. Os grandes empreendedores, sob o aval do governo, vão "engolindo" cada vez mais espaços, desconstruindo antigos territórios e impondo outro - o do mercado de lazer, especialmente nos anos 90, com o "Governo das Mudanças".

O cenário litorâneo da cidade sofre, com isso, completa metamorfose: a praia, que há tempos era caracterizada pela forte presença de pescadores e que foi, posteriormente, "compartilhada" com a habitação de segmentos privilegiados passando, então, a apresentar uma paisagem marcada por chácaras, transforma-se em espaço de consumo (mercadoria). É a zona costeira o melhor lugar para investir e instalar bons negócios. Sobre isso, Aragão (2005) ressalta a concessão de créditos e isenções fiscais por parte do governo àqueles interessados na abertura de seu próprio negócio, atuando na área de hospitalidade com o estabelecimento de pousadas próximas à Beira-Mar, e nas áreas gastronômica e de entretenimento.

As relações sociais e econômicas se dão por meio de uma materialidade espacial, o preocupante é, todavia, um maior incentivo à captação de megaprojetos, como aponta Rodrigues (1997, p. 24), sem uma análise mais aprofundada quanto à sustentabilidade do ambiente:

Para o Brasil a política da Embratur está evidentemente privilegiando megaprojetos. Em abril de 1991, cinco governadores estiveram reunidos com o objetivo de criar um projeto integrado do turismo na Região Nordeste. Já contam com financiamentos de U\$500 milhões para a construção de grandes resorts, em que a cadeia espanhola Meliá projeta a construção de 30 unidades hoteleiras, apostando na previsão de que o Nordeste brasileiro será o Mediterrâneo do ano 2000.

Como a cadeia Meliá, uma série de outras transforma a costa fortalezense em espaço transnacional, e afirma a nova territorialidade: o litoral é orientado, principalmente, para o uso de turistas e o desempenho de atividades do ramo. Isso se dá 
sob a justificativa de que a globalização, que alcança a cidade por intermédio do turismo, permite o intercâmbio entre as diversas culturas e riquezas, porém, ao mesmo tempo em que os lugares se encontram cada vez mais interligados pelas facilidades proporcionadas pela tecnologia dos transportes e meios de comunicação, o processo de globalização expõe uma nova forma de exploração, permitindo que os limites à atuação de grandes empresas sejam derrubados.

Para Benevides (1998, p. 29): “O processo de globalização vai estabelecendo a unificação hierarquizada dos lugares, todavia sem provocar a homogeneização do planeta”. Assim, países desenvolvidos, através de suas multinacionais, podem atuar livremente na exploração das paisagens naturais que países de economia dependente ainda podem oferecer. O "paraíso perdido" dos países tropicais é tomado por essas empresas que instalam equipamentos "pesados" sob o incentivo Estatal trazendo, muitas vezes, danos ao meio ambiente.

A verticalização exacerbada da zona costeira de Fortaleza pode ser citada como um exemplo do descaso dos governos frente ao bem estar da comunidade local, ao passo que esse processo pode favorecer a formação de "ilhas de calor", provocadas pelo barramento da velocidade e intensidade dos ventos e o consequente aumento da temperatura nas áreas mais centrais da cidade.

Esse cenário pode ser considerado fruto da política econômica praticada durante o "milagre brasileiro", quando o crescimento econômico é identificado à própria noção de desenvolvimento. Diante disso, a questão ambiental passou a ser encarada como um obstáculo ao progresso. Durante esse período:

[...] o turismo e o lazer emergem com maior força, mas como não há regulamentação adequada ao uso e ocupação do solo, ele se dá de forma desordenada e problemática. A ocupação de áreas indevidas, como os mangues, dunas móveis e a própria verticalização da orla marítima de Fortaleza começam a causar problemas (CORIOLANO, 1998, p. 74).

Por volta dos anos 90, no entanto, essa ética econômico-desenvolvimentista se mostra inviável, abrindo espaço ao discurso do desenvolvimento sustentável, cujo principal promotor no âmbito turístico foi o PRODETUR. Esse Programa objetiva a implantação e melhoria da infraestrutura necessária à instalação de equipamentos

\footnotetext{
${ }^{8}$ Milagre Econômico Brasileiro: crescimento econômico acelerado ocorrido durante o Regime Militar no Brasil, compreendendo o período entre 1968 e 1973 (CORIOLANO, 1998).
} 
diversos voltados para a atividade turística, possibilitando o crescimento do turismo receptivo na região do litoral nordestino. No Ceará de $573 \mathrm{Km}$ de litoral, os quais podem exercer a afamada "vocação natural" para o turismo, o PRODETUR-CE permitiu a implementação do sistema viário.

Com base em dados apresentados por Dantas (2002), o Governo do Estado e o Banco Interamericano de Desenvolvimento concederam investimento de U\$ 29.200.000,00 a tal fim. Assim, o sistema viário que valorizava o sertão cede lugar a outro que, partindo de Fortaleza, abre-se em sentido leste-oeste, como a abraçar o Atlântico. Fortaleza figura como portão de entrada. "Chegando à 'Cidade do Sol', os consumidores de praia podem ter acesso a todo conjunto do litoral cearense" (DANTAS, 2002, p. 98). Dessa forma, outras localidades do litoral cearense passam a ser englobadas pelo mercado imobiliário, inicialmente, por meio da prática do veraneio, carregando consigo toda série de conflitos.

Novas zonas litorâneas são, pois, loteadas, oferecendo-se como principal produto a vista para o mar, e quando esta já não é possível pela distância da praia, vende-se ao menos a brisa marinha: a "brisa do mar" torna-se, dessa maneira, chamativo para negócios imobiliários. Percebe-se daí que os elementos naturais posicionam-se no centro dessa esfera econômica exigente por transformações do espaço, as quais acompanhem as necessidades dos novos usuários - veranistas, empreendedores, turistas.

Tais transformações, no entanto, se não levarem em consideração os interesses da população local, podem desembocar em segregação, não apenas espacial, mas social, pois em muitos casos as oportunidades que, em potencial, o turismo ofereceria à comunidade local são tomadas por aqueles que já possuem poder econômico e exercem influências também sobre o âmbito político. Diante disso, a dita ética sustentável acaba por ser ferida quando o cooperativismo, a natureza, a cultura local são desrespeitados (CORIOLANO, 2003).

Como percebe Aragão (2005, p. 69), “[...] a publicidade imobiliária contemporânea contempla de forma especial a vista para o mar, tendência do turismo de massa". Paralelamente a isso, um monumental paredão de edifícios é erigido, contornando o mar. E a ausência de áreas verdes leva à reflexão e à certeza de que o conceito de desenvolvimento adotado na cidade deve ser repensado, no sentido de 
buscar, como pensa Silva (2001), a convivência com a natureza, de maneira a crescer com ela e não contra ela.

O desenvolvimento social sustenta-se na satisfação das necessidades humanas fundamentais, na geração de níveis crescentes da independência dos indivíduos, na articulação orgânica dos seres humanos com a natureza, com a tecnologia, a fim de que possam se integrar nos processos globais, respeitando os valores e os comportamentos locais (CORIOLANO, 2003, p. $33)$.

Seguindo a tendência atual a direcionar o uso da região costeira para a atividade turística, percebem-se as várias obras de cunho público-urbanístico capazes de reforçar o processo de formulação da identidade marítima de Fortaleza, objetivando-se a consolidação de uma possível "imagem pública”, como estuda Kevin Lynch (1997).

Segundo o autor, estas imagens são compartilhadas entre segmentos de habitantes de determinada cidade. Percebe-se ai que a forma é potencialmente capaz de evocar uma forte imagem (imaginabilidade) em observadores que mantém entre si certo grau de homogeneidade, seja com relação à idade, cultura, profissão, nível social etc. "Cada indivíduo cria e assume sua própria imagem, mas parece existir um consenso substancial entre membros do mesmo grupo" (LYNCH, 1997, p. 8). Assim, buscandose alcançar essas "imagens consensuais", pode-se verificar a produção de espaços, em Fortaleza, estrategicamente planejados e sugestivos. Citando ainda Lynch (1997, p. 7):

As imagens ambientais são o resultado de um processo bilateral entre o observador e seu ambiente. Este último sugere especificidades e relações, e o observador - com grande capacidade de adaptação e à luz de seus próprios objetivos - seleciona, organiza, e confere significado àquilo que vê.

Sob essa perspectiva, são citados aqui equipamentos urbanos, tais como o “Centro Dragão do Mar de Arte e Cultura”, (re) funcionalizando-se seu entorno, e o projeto "Acquário Ceará" (em fase de idealização), o qual pretende explorar a identidade marítima construída. Tal identidade, por vezes, acaba por fortalecer a descaracterização de sujeitos históricos como o jangadeiro, transformando-os em simples sujeito "típico" dotados de exotismo aos olhos do forasteiro. O mesmo acontece com a jangada que, de instrumento de trabalho e característico de um modo de viver específico, acaba por ser apresentada quase como mero artefato "decorativo", tendo seus significados culturais muitas vezes esvaziados. 
Obras de grande impacto que geralmente são projetadas preveem a transferência de moradores para conjuntos habitacionais, revestindo-se portanto como um impacto sobre a vida social e econômica dessas pessoas, afinal, muitas das famílias sobrevivem da pesca e podem ser prejudicadas se afastadas do mar. Além disso, as relações pessoais e os vínculos de amizade e até ambiental correm o risco de ser quebrados.

Portanto, para qualquer intervenção desse porte há a necessidade de um planejamento capaz não apenas de permitir a transferência de territórios de pobreza da orla para áreas periféricas. Muitos têm interesse em ampliar a orla turística de Fortaleza, porém, torna-se imprescindível a preocupação no sentido de que não sejam ampliados também os problemas por esta carregados, perpetuando-se contrastes, segregação e disfunções urbanas, como espaço de expressão de individuais interessados em concentração, não apenas econômica, mas no que diz respeito ao próprio direito à cidade.

\section{REFERÊNCIAS}

ARAGÃO, R. F. Das práticas marítimas à elaboração da imagem turística de Fortaleza/Ceará. 132 f. Dissertação (Mestrado em Desenvolvimento e Meio Ambiente). Programa Regional em Desenvolvimento e Meio Ambiente - PRODEMA. Universidade Federal do Ceará, Fortaleza, 2005.

ARANTES, A. A. Patrimônio Cultural e Nação. Tradução de Andrea Borghi. In: ARAÚJO, Â. M. C. (Org.). Trabalho, cultura e cidadania: um balanço da história social brasileira. São Paulo: Scritta, 1997.

AZEVEDO, O. de. Fortaleza descalça: reminiscência. 2. ed. Fortaleza: UFC/ José de Alencar, 1992.

BENEVIDES, I. P. Turismo e PRODETUR: Dimensões e olhares em parceria. Fortaleza: EUFC, 1998.

BERNARDES, J. A; FERREIRA, F. P. M. Sociedade e Natureza. In: CUNHA, S. B; GUERRA, A. J. T. A Questão Ambiental: Diferentes Abordagens. Rio de Janeiro: Bertrand Brasil, 2003.

CALVINO, I. As cidades invisíveis. Tradução de: Diogo Minarde. São Paulo: Companhia das Letras, 1990. 
CASTRO, J. L. de. Fatores de localização e expansão da cidade de Fortaleza. Fortaleza: UFC, 1977.

COELHO, M. C. N. Impactos Ambientais em Áreas Urbanas - Teorias, conceitos e métodos de pesquisa. In: GUERRA, J. T; CUNHA, S. B. (Orgs.). Impactos Ambientais Urbanos no Brasil. 4. ed. Rio de Janeiro: Bertrand Brasil, 2006.

CORIOLANO, L. N. M. T. O turismo litorâneo cearense: do local ao global. As comunidades de Flecheiras e Guajiru - Trairí - Ceará. Dissertação (Mestrado em Geografia). Centro de Ciência e Tecnologia. Universidade Estadual do Ceará, Fortaleza, 1998.

CORIOLANO, L. N. M. T. O desenvolvimento voltado às condições humanas e o turismo comunitário. In: CORIOLANO, L. N. M. T; LIMA, L. C. (Orgs.). Turismo comunitário e responsabilidade socioambiental. Fortaleza: EDUECE, 2003.

CORIOLANO, L. N. M. T; SILA, S. C. B. de M. Turismo e Geografia: abordagens críticas. Fortaleza: EDUECE, 2005.

DANTAS, E. W. C. Mar à vista: estudo sobre a maritimidade em Fortaleza. Fortaleza: Museu do Ceará / Secretaria de Cultura e Desporto do Ceará, 2002.

FUNDAÇÃO INSTITUTO DE PESQUISA E INFORMAÇÃO DO CEARÁ IPLANCE. Anuário Estatístico do Ceará 1994. Fortaleza, 1995.

GIRÃO, R. Geografia estética de Fortaleza. Fortaleza: Imprensa Universitária, 1959.

GONDIM, L. M. P. Imagem da cidade ou imaginário sócio-espacial? Reflexões sobre as relações entre espaço, política e cultura, a propósito da Praia de Iracema. In: Revista de Ciências Sociais, Cidade e Cidadania. V. 32, n. 1/2, 2001, p. 7-21.

JUCÁ, G. N. M. Verso e reverso do perfil urbano de Fortaleza (1945-1960). 2. ed. São Paulo: Annablume; Fortaleza: Secretaria de Cultura e Desporto do Estado do Ceará, 2003.

LYNCH, K. A imagem da cidade. São Paulo: Martins Fontes, 1997.

MEIRELES, H. C. R. Mito do Caribe nordestino: análise comparativa das editoriais de cidade e turismo do Diário do Nordeste (junho/julho de 1994). Monografia (Graduação em Comunicação Social). Universidade Federal do Ceará, Fortaleza, 1994.

RODRIGUES, A. B. Turismo e Espaço: rumo a um conhecimento transdisciplinar. São Paulo: HUCITEC, 1997.

SILVA, J. B. da S. Nas trilhas da cidade. Fortaleza: Museu do Ceará / Secretaria de Cultura e Desporto do Ceará, 2001. 
SILVA FILHO, A. L. M. A cidade e o patrimônio histórico. Fortaleza: Museu do Ceará / Secretaria da Cultura do Estado do Ceará, 2003.

Recebido em: 28-11-2011.

Aprovado em: 28-12-2011. 